\title{
LESK A BIEDA MATEMATICKÝCH RIEŠENÍ V PSYCHODIAGNOSTIKE ${ }^{1}$
}

\author{
VLADIMÍR DOČKAL ${ }^{2,3}$
}

\begin{abstract}
Abstrakt: Ked' pred sto rokmi začala psychológia kvantifikovat' svoje zistenia, získala si rešpekt a možnost' zaradit' sa do sveta vedy - tak ako sa veda v tých časoch chápala. Kvantitatívny prístup je charakteristický najmä pre psychometriku, ktorá sa vduchu pozitivizmu stala ked' nie úplným synonymom psychodiagnostiky, tak aspoň prevládajúcim smerom v nej. Aj dnes má pozitivistická paradigma v psychológii silnú pozíciu, no čoraz viac sa uplatňujú rôzne nové (kvalitatívne) pohl'ady. Je preto namieste zamysliet' sa nad úlohou matematiky v psychologickom poznaní, osobitne v psychodiagnostike. Príspevok kriticky hodnotí možnosti matematiky pri koncipovaní teórie, na ktorej je psychologický test založený, pri výbere položiek a overovaní psychometrických charakteristík testu a pri tvorbe testových noriem. Dokladá užitočnost' matematických prístupov, ale upozorňuje aj na ich limity. Matematika je v psychodiagnostike nezastupitel'ná, je však iba pomocníkom, ktorý nemôže nahradit' kvalifikované psychologické usudzovanie.
\end{abstract}

Kl'účové slová: psychometrika, matematická štatistika, teória testu, položky, normy

Možnost' kvantifikovat' psychické procesy urobila z pôvodne špekulatívnej psychológie „vedu“, ako bola chápaná na konci 19. a temer v celom 20. storočí (pozri napr. Gould, 1998). Kvantitatívny prístup sa uplatnil vo výskumoch aj v psychodiagnostike - vznikla psychometrika (Urbánek a kol., 2011). Tá sa však, žial', dlho vyvíjala nie ako teoretická disciplína naviazaná na vedeckú psychológiu, ale plnila predovšetkým inštrumentálnu úlohu opierajúc sa iba o matematickú štatistiku (tamtiež). V tejto podobe sa na dlhý čas stala temer synonymom psychodiagnostiky. Hoci je pojem psychodiagnostiky širší zahŕňa aj kvalitatívny klinický prístup (Halama, 2011), psychologické meranie je v psychodiagnostike cenené a bezpochyby užitočné. Ide však o jeho podobu. 0 nej sa síce v poslednom období v literatúre dost' diskutuje, no hlavný prúd uvažovania nie je zatial' novými myšlienkami zasiahnutý (Urbánek a kol., 2011).

Kvantitatívna psychológia a psychometrika vyvíjajú od šest'desiatych rokov minulého storočia čoraz prepracovanejšie a sofistikovanejšie matematické postupy (nové podoby

\footnotetext{
${ }^{1}$ Podkladom tohto textu bol referát prednesený na konferencii Psychologická diagnostika dětí a dospívajících v Brne 30.6.2011.

2 Výskumný ústav detskej psychológie a patopsychológie, Cyprichova 42, 83105 Bratislava

${ }^{3}$ Ústav aplikovanej psychológie, Fakulta sociálnych a ekonomických vied UK, Mlynské luhy 4, 82105 Bratislava
} 
faktorovej analýzy či teória odpovede na položku - pozri napr. Halama, 2011; Urbánek a kol., 2011; Žitný, 2014). Avšak nástup či skôr znovuobjavenie kvalitatívnej metodológie a jej rozvoj vposlednom desat'ročí minulého storočia kvantitatívne prístupy v psychológii spochybnil (pozri napr. Bačová, 2009). Aj to je dôvod zamýšl’at' sa nad úlohou matematiky v psychologickom poznaní a v psychodiagnostike zvlášt'.

Matematika sa v psychodiagnostike uplatňuje

- pri tvorbe teórie, na ktorej je psychologický test založený;

- pri výbere testových položiek;

- pri overovaní psychometrických charakteristík testu;

- pri tvorbe testových noriem.

Každej z týchto oblastí venujem teraz stručnú pozornost'.

\section{Psychologická teória}

Prvé testy v psychológii vznikali na základe implicitných teórií ich autorov; opierali sa skôr o ich klinickú skúsenost' a intuíciu (pozri napr. Nedvěd, 2011), než o explicitnú vedeckú teóriu. Chcem však zdôraznit', že všetky vedecké teórie vznikajú explifikáciou imlicitných teórií odborníkov. Samozrejme, že pri tom okrem osobného presvedčenia zohrávajú dôležitú úlohu informácie získané štúdiom literatúry a poznatky získané výskumom, vrátane jeho kvantitatívneho spracovania.

Nové testy sa zväčša opierajú o explicitné teórie. Teoretické ukotvenie testu sa pokladá za jeden zo znakov jeho kvality (Urbánek, Širůček, 2010). Vplyvná skupina autorov je presvedčená, že teóriu treba tvorit’ na základe matematických výpočtov, predovšetkým pomocou faktorovej analýzy. Tak sa napríklad Woodcockov-Johnsonovej kognitívna batéria (Ruef et al., 2003) opiera o faktorovoanalytickú teóriu inteligencie známu ako CHC (Cattel-Horn-Carroll - pozri napr. Furman, 2005). Autori poslednej revízie známeho inteligenčného testu R. Amthauera (2005) sa zasa pokúsili prispôsobit' pôvodnú štruktúru testu teórii, ktorú vytvorili ako kompiláciu faktorovoanalytických teórií vrátane CHC.

Som presvedčený, že aplikácia faktorovej analýzy môže pôvodnú teóriu spresnit', žiadna teória sa však nedá vypočítat'. O údajoch, ktoré do výpočtu vložíme, nerozhoduje totiž matematika, ale úvaha (implicitná teória) autora. Napríklad: CHC obsahuje faktor sluchovej diskriminácie - jednoducho preto, že J. B. Carroll na základe svojej implicitnej teórie zaradil do výpočtov aj úlohy postihujúce túto schopnost'. Podobne ako väčšina teórií inteligencie však neobsahuje faktor tvorivosti. O tom, či tvorivost' možno považovat' za súčast' inteligencie, však nerozhoduje výsledok faktorovej analýzy, ale autor teórie. J. P. Guilford (1967) na základe svojich teoretických úvah zaradil do štruktúry inteligencie aj faktory tvorivosti a iným typom faktorovej analýzy ich potvrdil. J. R. Sternberg (2001) hovorí o tvorivej inteligencii len na základe teoretickej analýzy problematiky, faktorovú analýzu k tomu nepotrebuje. Je preto jeho teória menejcenná? 
I. Ruisel (2004), ktorý študuje inteligenciu mimo rámca psychodiagnostiky, konštatuje, že faktorovoanalytické teórie inteligencie sú dnes na ústupe.

Stanovenie faktorovej štruktúry testov S-B (Thorndike et al., 1995) či WISC (Wechsler, 2002) možno uviest' ako príklady adekvátneho použitia faktorovej analýzy na spresnenie teórie konkrétneho testu. Aplikácia faktorovej analýzy za účelom obsahového vymedzenia meraného konštruktu však nemusí byt’ adekvátna. Konkrétne WJ-IE (Ruef et al., 2003): je pamät’ a sluchová diskriminácia naozaj súčast'ou „schopnosti mysliet“', kam ich zarad'uje príručka?

Aké teda vidím problémy pri aplikácii faktorovoanalytických koncepcií v psychometrii? Zamysliet' sa treba predovšetkým nad dvomi otázkami:

- Je obsah každého faktoru či „trsu subtestov“ dostatočne logický (a psychologický)?

- Je vždy adekvátne interpretovat' testové výsledky podl'a faktorov, ako to odporúčajú príručky (napr. Amthauer et al. 2005)? Faktory boli odvodené z korelácií medzi subtestami vo vel'kom súbore, v individuálnom prípade však takéto vzt'ahy nemusia platit'. Faktorové (každé sumárne) skóre možno zmysluplne interpretovat' iba v prípade, že medzi skóre subtestov vo vnútri faktora nie sú vel'ké rozdiely.

\section{Výber testových položiek}

Výber konkrétnych položiek sa robí z väčšieho množstva navrhnutých položiek na základe položkovej analýzy tak, aby položky neboli príliš l’ahké ani príliš t’ažké a aby dobre diferencovali medzi skúšanými (Halama, 2011). Údaje o obt’ažnosti a diskriminačnej sile položiek sú pre zostavenie kvalitného testu nevyhnutné. Nemožno sa riadit' „pocitmi“ autora, tieto parametre treba skutočne vypočítat'. Aby mal výpočet zmysel, musí sa samozrejme realizovat' s údajmi získanými v adekvátnej referenčnej skupine (reprezentatívnom súbore, pozri nižšie).

Teória odpovede na položku (IRT) pracuje s komplexnejšími charakteristikami (pozri napr. Žitný, 2014). Je však otázne, či testy založené na IRT poskytujú skutočne presnejšie výsledky, a to vzhl'adom na dve skutočnosti:

- vstupné údaje (odpovede testovaného) sú vždy „soft data“;

- aj v prípade IRT sa na indivíduum aplikujú pravdepodobnostné poznatky získané výpočtom z údajov vel'kého súboru.

Napríklad obt’ažnost': V klasickej teórii testov vypočítame jediný koeficient, ktorý nám hovorí, aké percento všetkých testovaných konkrétnu položku správne vyrieši. Aj ked' vieme, že obt'ažnost' položky je dajme tomu 0,8 (80 \% správnych riešení), nič nám to nepovie o tom, ako bude túto položku riešit' konkrétna osoba. Dá sa predpokladat', že pre jedinca s vyššou úrovňou meranej schopnosti bude úloha l'ahká, no pre testovaného 
s podpriemernými schopnost’ami l'ahká byt' nemusí. Teória odpovede na položku nám ponúka sofistikovaný výpočet krivky, z ktorej odčítame, nakol'ko je položka obt’ažná pre jedinca s priemernou, podpriemernou i nadpriemernou úrovňou meranej schopnosti. No aj ked' viem, aká je odhadovaná úroveň testovaného, a na základe toho konštatujem, že má pri odpovedaní na konkrétnu položku 80-percentnú pravdepodobnost' úspechu, stále to neznamená, že práve on nepatrí medzi tých 20 \% l’udí, ktorí položku nevyriešia.

V tomto vidím zásadný problém tzv. adaptívneho testovania, t. j. prispôsobenia rozsahu testu konkrétnej osobe, a to tak pri klasickom testovaní, ako aj pri adaptívnom testovaní pomocou počítača, ktoré využíva teóriu odpovede na položku. Hoci podl'a predbežných výskumov majú adaptívne počítačové testy založené na IRT aj pri podstatnom znížení počtu zadávaných položiek stále dobré psychometrické charakteristiky (Žitný, 2014), riziko, že skrátenou verziou testu neodhadneme úroveň schopností konkrétneho testovaného správne, nie je zanedbatel'né. Je napríklad známe, že rozumovo nadané deti niekedy nevyriešia relatívne l'ahké úlohy a zabodujú až pri úlohách t’ažkých (Portešová, 2011). Adaptívne testovanie takéhoto diet'at'a by sa mohlo skončit' skôr, než na tie t'ažké úlohy dôjde. Počítač mu ich, na základe slabého výkonu v l’ahkých úlohách, vôbec neponúkne a potenciál diet'at'a ostane neodhalený.

\section{Overovanie psychometrických charakteristík}

Všetky druhy reliability (Halama, 2011; Urbánek a kol., 2011) je vhodné vyjadrit' pomocou vypočítaných koeficientov. Úlohou tvorcu či upravovatel'a testu je stanovit' adekvátne zdroje informácií o reliabilite (Standardy..., 2001) a im primerané štatistické ukazovatele. V testoch zameraných na osobnostné vlastnosti je namieste zaoberat' sa stabilitou výsledkov v čase, v testoch sledujúcich aktuálne psychické stavy by to bolo kontraproduktívne.

Vo väčšine prípadov je vhodné posudzovat' reliabilitu okrem iného podl'a konzistencie odpovedí na položky zamerané na rovnakú vlastnost'. Zdá sa, že v súčasnosti sa pri tom nadužíva Cronbachov koeficient alfa (Urbánek, Širůček, 2010), ktorého výpočet ponúkajú bežne dostupné štatistické počítačové programy (napr. SPSS). Údaje o vnútornej konzistencii testu prispievajú aj k výberu položiek - položka, ktorá konzistenciu narúša, by mala byt' z testu vyradená. Pozor ale na privysoké koeficienty (Halama, 2011)! Môžu znamenat', že položky nezachytávajú dostatočne reprezentatívnu množinu situácií, v ktorých sa má sledovaná vlastnost' prejavovat'. Ak napríklad položím desat'krát tú istú, len rôzne naštylizovanú otázku, dostanem desat' zhodných odpovedí a koeficient konzistencie sa bude rovnat' jednej. Napriek absolútnej reliabilite bude však validita takto zostaveného „testu“ pochybná. Podl’a môjho názoru ekologickú validitu testu spochybňuje vnútorná konzistencia vyjadrená koeficientom vyšším než 0,95 . Pri nižších hodnotách samozrejme platí, že vyššia reliabilita je lepším predpokladom toho, aby test mohol byt’ pokladaný za validný (Halama, 2011; Urbánek a kol., 2011). 
Pri hl'adaní dôkazov o validite (Standardy..., 2001) sa vychádza z teórie. Pre získanie väčšiny týchto dôkazov je treba realizovat' empirický kvantitatívny výskum, v takom prípade ich možno predložit' v podobe čísel (koeficientov validity). D. Boorsboom so spolupracovníkmi (podl'a Urbánka a kol., 2011) súčasné prístupy ku kvantifikácii validity ostro kritizujú. Upozorňujú napríklad, že ak výsledok nejakého testu vysoko koreluje s výsledkom iného testu, nemusí to ešte znamenat', že testy merajú totožnú vlastnost'. V každom prípade odporúčam sústredit’ sa na to, čo klasická teória testov označuje ako obsahovú validitu a čo sa overuje expertnými posudkami obsahu položiek; ich zhodu samozrejme tiež možno vyjadrit' matematicky (Halama, 2011).

Podobne možno s pomocou matematiky vyjadrit' aj objektivitu testu chápanú ako zhodu výsledkov, ktoré s jeho pomocou získajú viacerí posudzovatelia (tamtiež; Urbánek et al., 2011). To je dôležité najmä pri takých psychodiagnostických nástrojoch, ktoré nemajú jednoznačne formalizované kritériá vyhodnocovania (napríklad pri projektívnych testoch či pri testoch tvorivosti).

\section{Tvorba testových noriem}

Pre možnost' využívat' test nielen vo výskume, ale ako nástroj individuálnej psychodiagnostiky, je nevyhnutné porovnat' odpovede testovaného s odpoved'ami referenčnej skupiny (teda s odpoved'ami typickými pre populáciu, do ktorej skúšaný patrí). To nám umožňuje aplikácia vhodných metód matematickej štatistiky.

Kruciálnou otázkou tvorby noriem je výber adekvátnej referenčnej skupiny (reprezentatívneho štandardizačného súboru). Náhodný výber $\mathrm{z}$ populácie je nerealizovatel'ný, d’alšie možné typy výberov uvádzajú všetky príručky kvantitatívnej metodológie (Ritomský, 2002; Hendl, 2004 a d’.). Najčastejšie sa používa tzv. kvótny výber; reprezentatívnost' súboru sa dosahuje stratifikáciou podla adekvátnych demografických kritérií. Je na odborníkoch realizujúcich štandardizáciu, aby zvolili kritériá, ktoré majú zásadný význam vo vzt’ahu k sledovanej vlastnosti. Súbor by mal byt' dostatočne vel'ký na to, aby sa zvolené kritériá dali uplatnit' (Dočkal, 2010). Pri „dolad'ovaní“ (vyvažovaní) súboru podl'a stratifikačných kritérií môže pomôct' matematika, nevyrieši však situáciu, ak je v niektorom podsúbore nedostatok osôb.

Príkladom takto nesprávne použitej matematiky môže byt' tvorba slovenského štandardizačného súboru testu WJ-IE. Podl'a príručky (Ruef et al., 2003) mal slovenský súbor 962 členov, z toho sedem $(0,7 \%)$ malo mad'arskú národnost'. Ked'že upravovatelia chceli zachovat' stratifikáciu podl'a etnickej príslušnosti a na Slovensku žije podl'a demografických údajov cca 11 \% Mad'arov, prisúdili výsledkom mad'arských probandov váhu 16. Je otázne, či je tvorba spoločných noriem pre rôzne etnické skupiny adekvátna. Ak sa ale mala dodržat’ národnostná skladba štandardizačného súboru, bolo nevyhnutné zaradit' do štandardizačného súboru väčší počet mad'arských probandov. Vel'kost' súboru síce nie je zárukou jeho reprezentatívnosti (Dočkal, 2010), podstatne však ovplyvňuje presnost' merania: čím početnejší je súbor, tým užší je interval 
spol'ahlivosti sledovaného parametra (Hendl, 2004). Priemerný výsledok siedmich osôb môže byt' zat'ažený vel'kou chybou; prisúdením uvedenej váhy sa táto (neznáma) chyba šestnást'krát vniesla do výsledných noriem testu.

Zásadnou myšlienkou, ktorú chcem na tomto mieste vyslovit', je, že testové normy sa nepočítajú, ale tvoria; výpočty sú iba nevyhnutným východiskom pre ich vypracovanie. Psychologickú realitu totiž nemožno vždy vyjadrit' pomocou matematického modelu. Podrobnejšie som sa tejto problematike venoval v iných štúdiách (Dočkal, 2009, 2010); tu uvediem niekol'ko príkladov neadekvátne vytvorených noriem:

Nalistujme si prevodové tabul'ky v českej príručke SON-R 21/2-7 (Tellegen et al., 2008). Až do veku temer 4 rokov je možné za nulový výkon v niektorom zo šiestich subtestov získat' štandardné skóre (ŠS) vyššie ako 1. Napríklad v subteste Mozaiky získa 2;5 ročné diet’a, ktoré nevyriešilo ani jednu úlohu, štandardné skóre 7 bodov (čo zodpovedá $\mathrm{IQ}=85$, teda nižšiemu priemeru). Transformácia hrubého skóre na štandardné prostredníctvom z-skóre sa realizuje na celej číselnej osi. Pri nízkej priemernej hodnote a sprava zošikmenej distribúcii, či vel'kej smerodajnej odchýlke je možné vypočítat' nenulové ŠS aj pre záporné hrubé skóre (bližšie pozri Dočkal, 2009), hoci záporné HS reálne neexistuje. Túto anomáliu autori noriem korigujú tým, že hodnoty šs pre záporné HS v tabul'kách neuvádzajú. Štandardné skóre pre nulový výkon však akceptujú tak, ako bolo vypočítané podl'a príslušného vzorca.

Hrubé skóre rovné nule znamená, že výkonový potenciál diet’at’a je maximálne taký, ako ukazuje príslušné ŠS, ale môže byt' aj l'ubovol'ne nižší. Test nie je v oblasti nízkeho výkonu v uvedenom veku dostatočne citlivý, preto neumožňuje vyjadrit' sa o reálnej výkonovej úrovni testovaného. Napriek tomu sa ŠS uvedené v tabul'ke započítava do sumárnych výsledkov, čím dochádza knekontrolovatel'nému nadhodnoteniu výkonov diet’at'a. Rovnaký postup je použitý v holandskej, ale aj nemeckej a slovenskej príručke SON-R $2 \frac{1}{2}-7$, lebo P. J. Tellegen, ktorý normy vypracoval, sa plne spolieha na presnost' výpočtov. Ten istý princíp (započítanie nenulového ŠS za nulový výkon v subteste) využívajú aj britské a české vydania testu WISC-III či nemecké a české vydania I-S-T 2000 R (Dočkal, 2010), čo pokladám za nenáležité.

Som presvedčený, že ak nechceme odhad schopností testovaného jednotlivca nekontrolovatel'ne nadhodnotit', nemali by sme subtesty, v ktorých nezískal ani bod, brat' pri výpočte sumárnych skóre do úvahy. Preto sme v slovenskej verzii WISC-III (Wechsler, 2006) nulovému výkonu neprisudzovali vážené skóre a výpočet celkového IQ umožňujeme robit’ iba na základe subtestov, v ktorých diet’a vyriešilo aspoň jednu položku. Interpretácia nulového výkonu v tom-ktorom subteste, ako aj interpretácia IQ stanoveného na základe menšieho počtu subtestov je potom vecou klinickej úvahy psychológa.

Posledným problémom, na ktorý chcem upozornit', je tvorba noriem vývinového testu, ktorého štandardizácia sa bežne robí prierezovým výskumom s rôznymi vekovými skupinami. Ked’že výkon diet’at’a s vekom narastá, malo by platit', že na dosiahnutie 
rovnakého štandardného skóre potrebuje starší proband získat' viac bodov hrubého skóre. To sa darí dodržat' pri výkonoch v pásme priemeru - prípadné nerovnomernosti v priemeroch získaných z výskumných údajov sa vyrovnávajú graficky alebo pomocou regresných rovníc (Říčan, 1977). V extrémnych polohách sa však (vd'aka nerovnakým rozptylom v rôznych vekových skupinách štandardizačného súboru) môžeme stretnút' s anomáliami, ktoré treba pri tvorbe prevodovej tabul'ky odstránit' manuálne, ako to urobili napríklad autori britskej príručky k testu WISC-III (Wechsler, 1992) a ako sme to realizovali aj v slovenskej príručke (Wechsler, 2006). Autor českých noriem (Boschek, 2002) sa však pýši tým, že k žiadnym úpravám nepristúpil a opiera sa o presne vypočítané hodnoty.

Ako sa takáto matematická rigoróznost' prejavila? Nalistujme si v českej príručke (Wechsler, 2002) napríklad prevodové tabul'ky pre 10;8-10;11 ročných a 11;0-11;3 ročných. Ak proband, ktorého sme testovali vo veku 10;8 rokov získal v subteste Kocky HS=15, hodnotíme ho štandardným skóre 3 (čo zodpovedá IQ=65, teda úrovni mentálnej retardácie). Predpokladajme, že toho istého probanda budeme retestovat' po pol roku a jeho absolútny výkon sa nezmení. Napriek tomu mu podla prevodovej tabul'ky prisúdime $\check{S} S=4$ (čo zodpovedá $\mathrm{IQ}=70$ a posúva ho do tzv. „hraničného pásma“). Podobne je tomu aj pri iných subtestoch; v prípade Kódovania je dokonca možné získat’ vo vyššom veku vyššie ŠS aj pri niekol'kobodovom znížení reálneho výkonu oproti nižšiemu veku.

Bolo by samozrejme nezmyslom interpretovat’ stagnujúci (či dokonca zhoršený) výkon diet’at'a ako jeho zlepšenie, ako k tomu nabáda tabul'kové štandardné skóre. Príčinu uvedenej anomálie som podrobne vysvetlil inde (Dočkal, 2009). Riešit' ju treba úpravou rozptylov v susedných vekových skupinách pred výpočtom štandardných skóre a manuálnou úpravou prevodovej tabul'ky, ak aj napriek tomu anomália pretrváva.

\section{Záver}

Matematika je nepostrádatel’nou pomocníčkou pri konštrukcii, štandardizácii aj interpretácii výsledkov psychodiagnostických testov. Bez uplatnenia matematickoštatistických postupov nemožno vytvorit' kvalitný psychometrický nástroj. Avšak matematika je pritom naozaj iba pomocníčkou:

- Teóriu, na ktorej je test založený, rozhodne nie je možné „vypočítat'“. Exploračná faktorová analýza je vhodným nástrojom istého typu výskumov a jej výsledky môžu prinášat' zaujímavé hypotézy. Nemala by sa však používat' na generovanie psychologickej teórie. Vypočítané faktory sú totiž matematickým artefaktom a nemusia zodpovedat' žiadnej psychickej realite (Gould, 1998). Niektoré aspekty teórie možno pomocou faktorovoanalytických postupov overovat', ale až ex post na to slúži tzv. konfirmačná faktorová analýza (Halama, 2011). 
- Tvorba testových noriem sa vždy opiera o presné výpočty. Konečné slovo pri nej však musí mat' psychologický úsudok, ktorý môže výsledky uskutočnených výpočtov korigovat'.

- Najpriamejšie je použitie matematiky pri zist'ovaní psychometrických charakteristík jednotlivých položiek i celého testu. Ktoré charakteristiky a akým spôsobom zist'ovat', o tom však opät' rozhoduje kvalifikovaný psychológ a interpretácia zistených koeficientov vrátane rozhodovania sa na ich základe o d’alšom postupe pri vývoji testu je tiež vecou jeho úvahy.

- Správna interpretácia testových výsledkov je nemyslitel'ná bez poznania ich štatistického pozadia (čo žial' nebýva našou silnou stránkou), musí však vždy íst' o psychologickú, nie štatistickú interpretáciu.

Odmietanie matematických aplikácií v psychológii je zaiste nerozumným extrémom, napokon aj kvalitatívny prístup s istým využitím matematiky ráta (pozri napr. Silverman, 2005). Rovnako nerozumné by však bolo spoliehat' sa na to, že matematika vyrieši psychologické problémy namiesto psychológie, a podl'ahnút' zdanlivej elegancii matematických riešení. Konečným arbitrom podoby testu, testových noriem aj interpretácie získaných výsledkov musí byt’ odborná psychologická úvaha. 0 využití konkrétnych matematických postupov $\mathrm{v}$ psychodiagnostike vždy rozhoduje autor (upravovatel', používatel') testu.

\section{Literatúra}

Amthauer, R., Brocke, B., Liepman, D., \& Beauducel, A. (2005). Test struktury inteligence I-S-T 2000 R. První české vydání. Upravila: A. Plháková. Praha: Testcentrum.

Bačová, V. (2009). Súčasné smery v psychológii. Bratislava: Veda.

Boschek, P. (2000). Tabulky norem a psychometrické vlastnosti české verze testu WISC-IIIUK. Praha: IPP ČR.

Dočkal, V. (2009). Matematika a zdravý rozum pri tvorbe testových noriem [CD]. In L. Golecká, J. Gurňáková, \& I. Ruisel (eds), Sociálne procesy a osobnost' 2008 (pp. 45-56). Bratislava: ÚEPsSAV.

Dočkal, V. (2010). Metodologické problémy štandardizácie testov schopností určených pre deti a mládež [CD]. In M. Gregussová, \& E. Farkašová (eds), Psychológia diet’at’a: Výskum a prax. Bratislava: VÚDPaP.

Furman, A. (2005). Teória inteligencie Gf-Gc ako východisko testovej batérie Woodcock-Johnson international editions. Psychológia a patopsychológia diet'at'a, 40, 347-361.

Gould, S. J. (1998). Jak neměřit člověka. Praha: NLN.

Guilford, J. P. (1967). The nature of human intelligence. New York: McGraw-Hill.

Halama, P. (2011). Princípy psychologickej diagnostiky. 2. dopln. vyd. Trnava: FFTU.

Hendl, J. (2004). Přehled statistických metod zpracování dat. Praha: Portál. 
Nedvěd, J. (2011). Střípky z historie Wechslerových škál [CD]. In: D. Heller \& P. Michálek (eds), 28. Psychologické dny. Cesty psychologie a psychologie cest (pp. 179-187). Praha: PEF ČZU; ČMPS.

Portešová, Š. (2011). Rozumově nadané děti s dyslexií. Praha: Portál.

Ritomský, A. (2002). Metódy psychologického výskumu: kvantitatívna analýza dát. Bratislava: Medzinárodné stredisko pre štúdium rodiny.

Ruef, M., Furman, A., \& Muñoz-Sandoval, A. (2003). Woodcock-Johnson. Medzinárodná edícia. Nashville: The Woodcock-Muñoz Foundation.

Ruisel, I. (2004). Inteligencia a myslenie. Bratislava: Ikar.

Říčan, P. (1977). Úvod do psychometrie. Bratislava: Psychodiagnostické a didaktické testy.

Silverman, D. 2005. Ako robit' kvalitatívny výskum. Bratislava: Ikar.

Standardy pro pedagogické a psychologické testování. (2001). Praha: Testcentrum.

Sternberg, R. J. (2001). Úspěšná inteligence. Praha: Grada.

Tellegen, P. J., Laros, J. A., \& Heider, D. (2008). SON-R 211/2-7. Neverbální inteligenční test. Praha: Hogrefe - Testcentrum.

Urbánek, T., Denglerová, D., \& Širůček, J. (2011). Psychometrika. Praha: Portál.

Urbánek, T., \& Širůček, J. (2010). Recenze psychodiagnostické metody, její průběh, výsledky a důsledky. Workshop. 28. Psychologické dny. Cesty psychologie a psychologie cest. ČMPS, Olomouc 9.9.2010.

Wechsler, D. (1992). WISC-IIIUK. Manual. London: The Psychological Corporation.

Wechsler, D. (2002). WISC-III. Wechslerova inteligenční škála pro děti. Autoři české verze D. Krejčířová, P. Boschek, J. Dan. Praha: Testcentrum.

Wechsler, D. (2006). WISC-IIISK. Wechslerova inteligenčná škála pre deti. Autori slovenskej verzie: V. Dočkal, E. Kretová, B. Kundrátová, B. Sedlačová, M. Tesař. Praha: Hogrefe - Testcentrum.

Žitný, P. (2014). Aplikácia teórie odpovede na položku v psychometrickej analýze a počítačovom adaptívnom testovaní. Kraków: Towarzyszstwo Słowaków w Polsce; FF TU. 


\title{
Vladimír Dočkal (2016): The splendor and miseries of mathematical solutions in psychodiagnostics
}

\begin{abstract}
When a hundred years ago psychology started to quantify its findings, it won its respect and an opportunity to integrate itself into the world of science - that is, as science was understood in those days. The quantitative approach is characteristic mostly for the psychometrics, which has become almost a complete synonym of psychodiagnostics in the light of positivism; if that is not so, then it has become at least a prevalent direction in it. Even today, the positivist paradigm in psychology has a strong position; however, rather new and diverse (qualitative) views receive an increasing support. It is therefore appropriate to reflect on the role of mathematics in psychological knowledge, particularly in psychodiagnostics. The contribution critically evaluates the possibilities of mathematics in framing the theory on which the psychological test is based, in selecting the items, and in verification of psychometric characteristics of the test and in development of test standards. It demonstrates the usefulness of mathematical approaches, but also draws attention to their limits. Mathematics is unsubstitutable in psychodiagnostics; however, it has only an assistant role that cannot replace qualified psychological reasoning.
\end{abstract}

Key words: psychometrics, mathematical statistics, test theory, items, norms 